\title{
Water Quality Assessment of Osse River, Gele-gele: A Tributary of Benin River, Southern Nigeria
}

*UWAIFO, OP; OMOGBEME, MI; OLOMUKORO, JO

\author{
Department of Animal and Environmental Biology, Faculty of Life Science, University of Benin, P.M.B 1154, Benin City, Nigeria \\ *Corresponding Author Email: uwaifoosaz@gmail.com
}

\begin{abstract}
The physical/chemical characteristics and some heavy metals of Osse River, Gele-gele, Southern Nigeria was assessed during the dry and wet seasons. Four stations were studied from upstream to downstream with an average distance of 500meters between each station. A total of twenty-one (21) physical/chemical parameters were studied. $\mathrm{pH}$ ranged from 6.2-7.5, Suspended Solid 4-48mg/l, Turbidity 0-39NTU, Electrical Conductivity $20-110 \mu \mathrm{S} / \mathrm{cm}$, Alkalinity 8-48mg/l, Chloride 7.1-17.7mg/l, Hardness 8-56mg/l, Phosphate 0.01-0.53mg/l, Sulphate 5-33mg/l, Nitrate 1.2-9.3mg/l, Dissolved Oxygen 2.0-8.4mg/l, Biochemical Oxygen Demand 0.6-5.8mg/l. Heavy metals level generally ranged from 0.1 to $1.8 \mathrm{mg} / 1$ for Iron, Zinc 0.0 to $0.93 \mathrm{mg} / 1$, Chromium 0.0 to $0.65 \mathrm{mg} / \mathrm{l}$, Cadmium 0.0 to $0.041 \mathrm{mg} / 1$, Lead 0.0 to $0.26 \mathrm{mg} / \mathrm{l}$, Manganese 0.0 to $0.082 \mathrm{mg} / \mathrm{l}$, Copper 0.0 to $0.059 \mathrm{mg} / 1$, Nickel 0.0 to $0.49 \mathrm{mg} / \mathrm{l}$. The mean concentration of metallic ions in Station 3 was significantly higher across the four sampled, with manganese, iron, cadmium, and copper responsible for this difference. Water Quality Index showed that all four stations had a range of 8.03-9.07. The concentration of the metals in the Osse river are within background concentration level, the mean Dissolved Oxygen and Biological Oxygen Demand obtained indicate the water is rated between fairly clean and clean, and the Water Quality Index indicates excellent water quality. Thus, the water is presently suitable for domestic use, but its quality may deteriorate with time if the current rate of anthropogenic activities around the water body is not curtailed.
\end{abstract}

\section{DOI: https://dx.doi.org/10.4314/jasem.v22i8.34}

Copyright: Copyright (C) 2018 Uwaifo et al. This is an open access article distributed under the Creative Commons Attribution License (CCL), which permits unrestricted use, distribution, and reproduction in any medium, provided the original work is properly cited.

Dates: Received: 31 July 2018; Revised: 26 August: 2018; Accepted: 30 August 2018

Keywords: Water Quality, Osse River, Gele-gele

The health of aquatic and terrestrial life is to a large extent a direct consequence of the health of surrounding water bodies. Water is one of the most important components of life and life without it is impossible. However, due to increasing anthropogenic activities and some natural processes, the quality of water is decreasing continuously and is posing a great threat to all forms of life including humans. In Nigeria and other developing nations, pollution of water resources has become a serious problem (Ogundiran $e t$ $a l ., 2010)$. It is a major cause for the spread of many epidemics and some serious diseases like cholera, tuberculosis, typhoid, diarrhea etc. The contaminants in these waters, reaching aquatic ecosystems directly or indirectly occur in different forms, and the most stable of them are the heavy metals (Adamiec and Helios-Rybicka, 2002). Water pollution heightens the threshold of heavy metals and this usually poses a serious threat to human health, natural and seminatural ecosystems (Battagglia et al., 2005). Rivers are a dominant pathway for metals transport (Mohiuddin et al., 2010).

River Osse is of immense importance to inhabitants along the river bank. They rely mainly on the river for their domestic water supply, fishing, and inter-village transportation. The river also receives effluents from sawmills and fallout from oil exploration activities. A few studies have been carried out on the physical and chemical characteristics of the surface water of Osse River, however, none has reported the water quality index (WQI) of this water body. The water quality index (WQI) is a time - based unit less number between 1 and 100 that expresses the overall quality of water as a reflection of the composite influence of the different water quality parameters in a particular location (Yisa et al., 2012). Therefore the use of WQI in the assessment of water quality is important in the monitoring and management of water source. This study is justified by the need to assess the water quality of Osse River using surface water to ascertain the level of anthropogenic influence in this water body. The aim of this paper is to present the data obtained as a consequence of the assessment of physical/chemical characteristics of a section of Osse River, Gele-gele a tributary of Benin River, Southern Nigeria and thus, provide baseline data on the water quality.

\section{MATERIALS AND METHODS}

Study Area: The study is on a stretch of Osse River that transverse through Gelegele to Iziedema 
Communities within the tropical rainforest belt in Ovia North-Earth Local Government Area of Edo State, Southern Nigeria. Osse River stretches between latitudes $06^{\circ} 12^{\prime} \mathrm{N}$ and $06^{\circ} 10^{\prime} \mathrm{N}$ and longitudes $05^{\circ} 20^{\prime} \mathrm{E}$ to $05^{\circ} 22^{\prime} \mathrm{E}$ in Ovia North-East Local Government Area of Edo State. Osse River drains into the Benin River which empties itself into the Atlantic Ocean. This study area falls within the rainforest belt of Nigeria, with a wet season (March to October) and a dry season period (November to March). The River is fairly wide and flanked by secondary vegetation of Hevea brasilensis, Elaeis guinensis, Bambusa sp. and shrubs. On the river are floating vegetation such as Lemna sp. and Eichorrnia crassipes. A prominent landmark in the area is the presence of Dubril oil company facilities and their tug boat and badge. A Sawmill is also located along the stretch of the river from Gelegele to lziedema.

Four sampling stations randomly were selected. Station 1 is located along a section of Osse River $06^{\circ}$ $15.236^{\prime} \mathrm{N}, 005^{\circ} 33.625^{\prime} \mathrm{E}$. This station is upstream and empties into station 2 partly because of a diversion that occurred some meters away from station 1. Station 2 is located at the entry point of Gelegele community $06^{\circ} 15.511^{\prime} \mathrm{N}, 005^{\circ} 34.355^{\prime} \mathrm{E}$. This station is residence to only but a few families and is used as a site for washing and bathing and receives other domestic waste because of its proximity to the settlers. Station 3 is located at Dubril oil flow station along the river $06^{\circ}$ $16.033 \mathrm{~N}, 005^{\circ} 34.960^{\prime} \mathrm{E}$. Gas is constantly flared at this station, and the flare is only fairly higher than the tallest building within the catchment area. This station is used as a site for washing and bathing by young people in the community because it is easily assessed. Station 4 is located at lziedema close to the evil forest along the Gelegele river course (downstream) at $06^{\circ}$ $16.458 \mathrm{~N}, 005^{\circ} 34.942^{`} \mathrm{E}$. Logging activities take place close to this station.

Sampling: Water samples were collected monthly for 10 months from September 2014 to June 2015, between $0700 \mathrm{hrs}$ and $0900 \mathrm{hrs}$ on each sampling day. A total of 27 samples were collected and analyzed during the study period. The in-situ measurement was carried out using a $\mathrm{pH}$ meter for $\mathrm{pH}$, TDS/Conductivity meter for electrical conductivity. Dissolved Oxygen and Biochemical Oxygen demand were estimated using Winkler's method. The BOD was carried out after 5 days of incubation at $20^{\circ} \mathrm{C}$. The other physical/chemical characteristics were examined using standard method (APHA, 1998). The heavy metals such as Iron, Lead, Cadmium, Zinc, Copper, Chromium, Manganese, Nickel, and Vanadium were determined using Atomic Absorption
Spectrophotometer (Buck Scientific Atomic Absorption Spectrophotometer).

Data analysis: Inter-station comparison was done using Analysis of variance (ANOVA) and Duncan Multiple Range (DMR) test was performed to determine the point of significant difference. All statistical analyses were performed using Microsoft Excel (2010) package and SPSS 16.0 (Ogbeibu, 2005). The Water quality index (WQI) was calculated using the Weighted Arithmetic Water Quality Index Method (Akter et al., 2016; Oboh and Agbala, 2017). The reference standard utilized for the calculation was the water quality criteria of the Nigerian Federal Ministry of Environment (FMEnv).

WQI was calculated by using the following equation: $\mathrm{WQI}=\Sigma \mathrm{Wi}$ Qi $/ \Sigma \mathrm{Wi}$

Where; Unit weight for each water quality parameter $(\mathrm{Wi})=\mathrm{K} / \mathrm{Si}$

Quality rating scale $(\mathrm{Qi})=100[(\mathrm{Vi}-\mathrm{Vo}) /(\mathrm{Si}-$ Vo)]

$\mathrm{K}$ (proportionality constant) is calculated as $\mathrm{K}=1 / \Sigma$ (1 / Si)

$\mathrm{Vi}=$ Estimated Concentration of the $\mathrm{i}$ th parameter of interest in the analysed water.

$\mathrm{Vo}=$ The ideal value of the $\mathrm{i}$ th parameter in pure water $\left(\mathrm{Vo}=0\right.$ if $\mathrm{pH}=7.0$; and $\left.\mathrm{DO}=14.6 \mathrm{mgl}^{-1}\right)$

$\mathrm{Si}=$ Recommended Standard value of the ith parameter by the FMEnv.

Table 1 illustrates water quality ratings according to the Weighted Arithmetic Water Quality Index method (Tyagi et al., 2013)

\begin{tabular}{lll}
\multicolumn{3}{c}{ Table 1: The rating of water quality } \\
\hline Levels & Rating of Water Quality & Grading \\
\hline $0-25$ & Excellent water quality & $\mathrm{A}$ \\
$25-50$ & Good water quality & $\mathrm{B}$ \\
$51-75$ & Poor water quality & $\mathrm{C}$ \\
$76-100$ & Very poor water quality & $\mathrm{D}$ \\
$>100$ & Unsuitable for drinking purposes & $\mathrm{E}$ \\
\hline
\end{tabular}

\section{RESULT AND DISCUSSION}

Physicochemical Characteristics: The results of the physical/chemical characteristics of water from Osse River at the different sampling stations is illustrated summarized in Table 2. The $\mathrm{pH}$ of the river ranged from 6.2-7.5 indicating that the river was slightly acidic to moderately alkaline and falls within the WHO limit. There was no significant difference across the sampled stations. This $\mathrm{pH}$ range agrees with Welcome (1979) that rivers that flow through 
rainforest regions are slightly acidic to neutral. This is due to the humic acid content arising from the decompositions and oxidation of organic matter in them (Deekae, 2010). The range recorded in this study is very close to those recorded in the Niger Delta waters of Nigeria (Omoigberale and Ogbeibu, 2007). The Total Suspended Solids ranged from $4 \mathrm{mg} / \mathrm{l}$ $48 \mathrm{mg} / \mathrm{l}$ in this study and showed no significant difference across the stations. The average suspended solid exceeded the WHO limit, which may have been due to the amount of erosion around the upstream. The values obtained in this study is lower than that obtained from previous studies in Lagos Lagoon complex (Agboola et al., 2008). Turbidity ranged from $7 \mathrm{mg} / \mathrm{l}$ to $39 \mathrm{mg} / \mathrm{l}$ in the study area and there was no significant difference across the sampled stations. The average turbidity also exceeded WHO limit. The mean value decreased slightly from station 1 to 3 before slightly increasing in station 4; this could be attributed to the organic constituents and human activities in the river system (Anyanwu, 2012). Conductivity ranged from $20 \mu \mathrm{S} / \mathrm{cm}$ to $110 \mu \mathrm{S} / \mathrm{cm}$ in the study area. The average value did not exceed WHO standard. This indicates the basic characteristics of the freshwater body (Anyanwu, 2012). Chloride concentration which could be used to check for possible saline intrusion in future ranged from $7.06 \mathrm{mg} / 1$ to $21.18 \mathrm{mg} / \mathrm{l}$ in this study and was not significantly different across the station. The average value fell within WHO standard but was relatively lower than the values obtained in Ogba river and Osse River in Benin City, Owo River and Ologe lagoon in Lagos (Omoigberale and Ogbeibu 2007; Yusuf and Osibango, 2007; Anyanwu, 2012). This is also a clear indication that the river was completely freshwater type in all the study stations. The Nitrate concentration obtained was relatively high $(1.2 \mathrm{mg} / \mathrm{l}$ to $9.3 \mathrm{mg} / \mathrm{l})$ unlike those reported for some in-land waters by Omoigberale and Ogbeibu 2007. This could be attributed to influxes of nitrogen from outside sources. The average nitrate concentration fell however within WHO limit and was not significantly different across the sampled stations. The range of phosphate obtained was $0.01 \mathrm{mg} / 1-0.53 \mathrm{mg} / \mathrm{l}$ and was not significantly different across the stations. In 2007, Omoigberale and Ogbeibu reported higher values of $0.28 \mathrm{mg} / \mathrm{l}$ to $3.52 \mathrm{mg} / \mathrm{l}$ from Osse River and Anyanwu reported $0.10 \mathrm{mg} / 1$ to $1.44 \mathrm{mg} / 1$ in 2012 . The reason for the decreased Phosphate value, compared to other aquatic systems may be due to the heterotrophic uptake by micro-organisms, sediment adsorption, as well as removal by the currents (Anyanwu, 2012). Dissolved oxygen, which is a measure of the amount of oxygen that is freely available in water, is essential for sustaining aquatic life in any ecosystem. The average value $(4.27 \mathrm{mg} / \mathrm{l})$ obtained in this study is similar to that obtained in other tropical rivers (Imoobe and
Adeyinka, 2010; Anyamwu; 2012) from Ogba river. This value is slightly less than the permissible limit $(5 \mathrm{mg} / \mathrm{l})$ necessary to sustain aquatic life, an indication that the water quality was starting to deteriorate.

The Biological Oxygen Demand (BOD) is a measurement of the oxygen requirement of biodegradable organic wastes in water. Values less than $1.2 \mathrm{mg} / 1$ are considered clean, $3 \mathrm{mg} / 1$ fairly clean, $5 \mathrm{mg} / \mathrm{l}$ doubtful and $10 \mathrm{mg} / \mathrm{l}$ serious (Rim-Rukeh et al., 2006), thus high B.O.D is an indication of poor water quality. The average biochemical oxygen demand obtained in the study area was $1.87 \mathrm{mg} / \mathrm{l}$ and there was no significant difference across the stations, hence indicates the water is categorized between fairly clean and clean. Alkalinity values ranged between $6.0 \mathrm{mg} / 1$ to $48.0 \mathrm{mg} / \mathrm{l}$ in this study. The average value did not exceed WHO limit. The value in this study is lower than those obtained in other water bodies in Nigeria; Adebisi (1981), recorded $77.9 \mathrm{mg} / \mathrm{l}$ for Ogun river, Ogbeibu and Victor (1995) recorded a range of $14.7 \mathrm{mg} / \mathrm{l}-50.7 \mathrm{mg} / \mathrm{l}$ for Itawogba stream system, PortHarcourt. The total alkalinity of a water body is a reflection of its carbonate and bicarbonate profiles. However, low alkalinity values are indications of low carbonate and bicarbonate ions in the water, a reflection of the absence of limestone in the drainage basin (Imoobe and Oboh, 2003). Iron was the highest occurring heavy metal in the surface water of Osse River with an average mean of $0.64 \mathrm{mg} / \mathrm{l}$ which is lesser than WHO limit. This was expected because it has been reported that Iron occurs at high concentration in Nigeria soil (Asaolu et al., 1997; Asaolu and Olafe, 2004). Similarly, Eddy and Ukpong (2002) reported that Iron had the highest concentration in upper Calabar River. The value obtained in this study is lower than that obtained in Ogba River (Anyanwu, 2012) and Itaogbolvin Ondo (Adefemi and Awokunmi, 2010). The Zinc concentration in the surface water of Osse River had an average mean of $0.23 \mathrm{mg} / \mathrm{l}$ which is less than the WHO limit. The average value was significantly higher than that in Ogba River Benin City (Anyanwu, 2012) and lower than that of River Ganga (0.37mg/l) (Kar et al., 2008) Ona River (3.2mg/l) (Adefemi and Awokunmi, 2010) and Jabi Lake (4.72 mg/l) (Umar and Ebong, 2013). The Average Chromium concentration found in Osse River was $(0.13 \mathrm{mg} / \mathrm{l})$ which was greater than WHO limit and was not significantly different across the sampled stations. This value was higher than that reported by Ogbeibu and Oribhabor (2009) on the assessment of heavy metals on Niger Delta creek $(0.025 \mathrm{mg} / \mathrm{l})$ and also that reported by Begum et al. (2009) $(0.0025 \mathrm{mg} / \mathrm{l})$ in Madivala lake. Adefemi and Awokunmi (2010) reported an average Chromium

UWAIFO, OP; OMOGBEME, MI; OLOMUKORO, JO 
concentration of $0.2 \mathrm{mg} / \mathrm{l}$ in Itaogbolu area of Ondo state.

Table 2: Mean \pm SE values of investigated physical and chemical characteristics of Gelegele River (September 2014 to June 2015)

\begin{tabular}{|c|c|c|c|c|c|c|}
\hline Parameters & $\begin{array}{l}\text { Stationl } \\
\text { Mean }=\text { SE } \\
\text { (Min, Max) }\end{array}$ & $\begin{array}{l}\text { Station2 } \\
\text { Mean } \neq \text { SE } \\
\text { (Min, Max) }\end{array}$ & $\begin{array}{l}\text { Station3 } \\
\text { Mean } \neq \text { SE } \\
\text { (Min, Max) }\end{array}$ & $\begin{array}{l}\text { Station4 } \\
\text { Mean } \neq \text { SE } \\
(\text { Min, Max) }\end{array}$ & P-Value & WHO \\
\hline $\mathrm{pH}$ & $\begin{array}{l}6.96 \pm 0.11 \\
(6.3,7.3)\end{array}$ & $\begin{array}{l}6.87 \pm 0.12 \\
(6.2,7.5)\end{array}$ & $\begin{array}{l}6.83=0.10 \\
(6.2,7.2)\end{array}$ & $\begin{array}{l}6.86 \pm 0.12 \\
(6.2,7.3)\end{array}$ & $P>0.05$ & $6.5-9.5$ \\
\hline Suspended S olid & $\begin{array}{l}11 \pm 1.78 \\
(4,25)\end{array}$ & $\begin{array}{l}14 \pm 4.12 \\
(7,48)\end{array}$ & $\begin{array}{l}10 \pm 1.83 \\
(6,24)\end{array}$ & $\begin{array}{l}9.5=1.85 \\
(5,24)\end{array}$ & $p>0.05$ & 3 \\
\hline Turbidity(NTU) & $\begin{array}{l}17 \pm 2.73 \\
(7,38)\end{array}$ & $\begin{array}{l}16 \pm 3.52 \\
(7,39)\end{array}$ & $\begin{array}{l}16 \pm 2.75 \\
(8,37)\end{array}$ & $\begin{array}{l}17 \pm 3.22 \\
(7,38)\end{array}$ & $P>0.05$ & 5 \\
\hline Conductivity $(\mu \mathrm{S} / \mathrm{cm})$ & $\begin{array}{l}59=12.05 \\
(20,110)\end{array}$ & $\begin{array}{l}46 \pm 8.19 \\
(20,90)\end{array}$ & $\begin{array}{l}45 \pm 7.92 \\
(20,90)\end{array}$ & $\begin{array}{l}45 \pm 7.83 \\
(20,90)\end{array}$ & $p>0.05$ & 1200 \\
\hline Alkalinity & $\begin{array}{l}19=4.10 \\
8,36\end{array}$ & $\begin{array}{l}19=3.46 \\
(10,38)\end{array}$ & $\begin{array}{l}21+5.39 \\
(6,48)\end{array}$ & $\begin{array}{l}17 \pm 3.29 \\
(8,34)\end{array}$ & $p>0.05$ & 100 \\
\hline Chloride & $\begin{array}{l}10=0.80 \\
(7.1,14.1)\end{array}$ & $\begin{array}{l}13 \pm 1.65 \\
(7.1,21.2)\end{array}$ & $\begin{array}{l}12 \pm 1.16 \\
(8.4,17.7)\end{array}$ & $\begin{array}{l}11=1.37 \\
(7.1,17.7)\end{array}$ & $p>0.05$ & 250 \\
\hline Hardness & $\begin{array}{l}19=2.81 \\
(8,32)\end{array}$ & $\begin{array}{l}19=3.55 \\
(10,42)\end{array}$ & $\begin{array}{l}22 \pm 4.67 \\
(10,56)\end{array}$ & $\begin{array}{l}17 \pm 2.74 \\
(8,32)\end{array}$ & $p>0.05$ & 500 \\
\hline Phosphate & $\begin{array}{l}0.2 \pm 0.04 \\
(0.06,0.39)\end{array}$ & $\begin{array}{l}0.3 \pm 0.05 \\
(0.01,0.53)\end{array}$ & $\begin{array}{l}0.2 \pm 0.04 \\
(0.02,0.34)\end{array}$ & $\begin{array}{l}0.2 \pm 0.04 \\
(0.05,0.35)\end{array}$ & $p>0.05$ & 0.2 \\
\hline Sulphate & $\begin{array}{l}14.0 \pm 2.15 \\
(5,25)\end{array}$ & $\begin{array}{l}18+3.06 \\
(5,33)\end{array}$ & $\begin{array}{l}15 \pm 2.0 \\
(6,25)\end{array}$ & $\begin{array}{l}13 \pm 1.15 \\
(8,17)\end{array}$ & $p>0.05$ & 500 \\
\hline Nitrate & $\begin{array}{l}4.0 \pm 0.7 \\
(1.4,6.6)\end{array}$ & $\begin{array}{l}3.4 \pm 0.6 \\
(1.6,8.0)\end{array}$ & $\begin{array}{l}3.1 \pm 0.7 \\
(1.4,9.3)\end{array}$ & $\begin{array}{l}3.3 \pm 0.7 \\
(1.2,9.1)\end{array}$ & $p>0.05$ & 10 \\
\hline Do & $\begin{array}{l}4.3 \pm 0.7 \\
(2.2,8.4)\end{array}$ & $\begin{array}{l}4.2 \pm 0.7 \\
(2.0,7.6)\end{array}$ & $\begin{array}{l}4.1 \pm 0.6 \\
(2.0,6.7)\end{array}$ & $\begin{array}{l}4.5 \pm 0.7 \\
(2.1,7.8)\end{array}$ & $P>0.05$ & \\
\hline BOD & $\begin{array}{l}1.800 .3 \\
(0.6,3.6)\end{array}$ & $\begin{array}{l}2.1 \pm 0.46 \\
(0.7,5.1)\end{array}$ & $\begin{array}{l}1.6 \pm 0.3 \\
(0.4,3.3)\end{array}$ & $\begin{array}{l}2.0 \pm 0.3 \\
(0.7,5.8)\end{array}$ & $P>0.05$ & - \\
\hline Iron & $\begin{array}{l}0.8 \pm 0.12 \mathrm{ab} \\
(0.1,1.4)\end{array}$ & $\begin{array}{l}0.5 \pm 0.08 \mathrm{a} \\
(0.1,0.9)\end{array}$ & $\begin{array}{l}1.0=0.17 \mathrm{c} \\
(0.2,1.8)\end{array}$ & $\begin{array}{l}0.4 \pm 0.04 \mathrm{a} \\
(0.2,0.6)\end{array}$ & $* * \mathrm{p}<0.01$ & 3 \\
\hline Zine & $\begin{array}{l}0.2 \pm 0.04 \\
(0.1,0.41)\end{array}$ & $\begin{array}{l}0.2 \pm 0.06 \\
(0,0.58)\end{array}$ & $\begin{array}{l}0.4 \pm 0.11 \\
(0,0.93)\end{array}$ & $\begin{array}{l}0.1 \pm 0.05 \\
(0,0.41)\end{array}$ & $P>0.05$ & 3 \\
\hline Chromium & $\begin{array}{l}0.2 \pm 0.08 \\
(0,0.65)\end{array}$ & $\begin{array}{l}0.1 \pm 0.05 \\
(0,0.36)\end{array}$ & $\begin{array}{l}0.1 \pm 0.04 \\
(0.01,0.33)\end{array}$ & $\begin{array}{l}0.1=0.05 \\
(0,0.38)\end{array}$ & $P>0.05$ & 0.05 \\
\hline Cadmium & $\begin{array}{l}0.0001 \pm 0.0001 \mathrm{a} \\
(0,0.001)\end{array}$ & $\begin{array}{l}0.001 \pm 0.001 \mathbf{a} \\
(0,0.01)\end{array}$ & $\begin{array}{l}0.0157 \pm 0.005 b \\
(0,0.041)\end{array}$ & $\begin{array}{l}0.0006 \pm 0.0005 \mathrm{a} \\
(0,0.005)\end{array}$ & $* * \mathrm{p}<0.01$ & 0.003 \\
\hline Lead & $\begin{array}{l}0.016 \pm 0.007 \\
(0,0.05)\end{array}$ & $\begin{array}{l}0.025 \pm 0.011 \\
(0,0.09)\end{array}$ & $\begin{array}{l}0.034 \pm 0.010 \\
(0,0.09)\end{array}$ & $\begin{array}{l}0.059=0.031 \\
(0,0.26)\end{array}$ & $P>0.05$ & 0.01 \\
\hline Mang anese & $\begin{array}{l}0.038 \pm 0.010 \mathrm{~b} \\
(0.007,0.09)\end{array}$ & $\begin{array}{l}0.014 \pm 0.001 \mathrm{a} \\
(0.009,0.02)\end{array}$ & $\begin{array}{l}0.039 \pm 0.008 b \\
(0.012,0.082)\end{array}$ & $\begin{array}{l}0.014 \pm 0.003 \mathrm{a} \\
(0,0.034)\end{array}$ & $* \mathrm{P}<0.05$ & 0.4 \\
\hline Copper & $\begin{array}{l}0.007 \pm 0.002 \mathrm{a} \\
(0,0.018)\end{array}$ & $\begin{array}{l}0.010=0.003 \mathrm{ab} \\
(0,0.026)\end{array}$ & $\begin{array}{l}0.025 \pm 0.007 b \\
(0.001,0.059)\end{array}$ & $\begin{array}{l}0.010=0.002 \mathrm{ab} \\
(0.001,0.017)\end{array}$ & $* * \mathrm{p}<0.01$ & 2 \\
\hline Nickel & $\begin{array}{l}0.102 \pm 0.042 \\
(0,0.31)\end{array}$ & $\begin{array}{l}0.145 \pm 0.062 \\
(0,0.49)\end{array}$ & $\begin{array}{l}0.167 \pm 0.063 \\
(0,0.45)\end{array}$ & $\begin{array}{l}0.104 \pm 0.051 \\
(0,0.34)\end{array}$ & $\mathrm{P}>0.05$ & 0.02 \\
\hline Vanadium & $\begin{array}{l}0.003 \pm 0.001 \\
(0,0.013)\end{array}$ & $\begin{array}{l}0.004 \pm 0.002 \\
(0,0.014)\end{array}$ & $\begin{array}{l}0.010 \pm 0.004 \\
(0,0.027)\end{array}$ & $\begin{array}{l}0.001 \pm 0.0007 \\
(0,0.0006)\end{array}$ & $P>0.05$ & 0.01 \\
\hline
\end{tabular}

The average Cadmium concentration in this study was $0.004 \mathrm{mg} / \mathrm{l}$ and was greater than WHO limit and was highly significantly different across the sampled stations with station 3 having the highest value. This value obtained from this study was slightly higher than the Cadmium concentration $(0.0012 \mathrm{mg} / \mathrm{l})$ obtained in Avsar River turkey (Ozturk et al., 2009) and lower than the value obtained from the Niger Delta creek $(0.028 \mathrm{mg} / \mathrm{l})$ and Jabi lake $(0.28 \mathrm{mg} / \mathrm{l})$ (Ogbeibu and Oribhabor, 2009; Umar and Ebong 2013). The mean Lead concentration $(0.034 \mathrm{mg} / \mathrm{l})$ of the surface water is higher than the WHO limit but not significantly different across the stations. The lead concentration obtained in this study is similar to the findings of Omoigberale and Ikponmwosa-Eweka (2010) $(0.023 \mathrm{mg} / \mathrm{l})$ in their study of Ovia river. Nickel concentration of surface water had a mean value of $0.130 \mathrm{mg} / \mathrm{l}$ which was higher than WHO limit and showed no significant difference across the stations. The average concentration obtained is in contrast to below the detection limits (BDL) observed by Ayas et al. (2007), Ozturk et al. (2009), Nongbri and Syiem (2012). This result was similar to that obtained by Adefemi and Awokunmi (2010) (0.1 mg/l) in Itaogbolu area of Ondo state. Mean Manganese concentration in this study was $0.026 \mathrm{mg} / \mathrm{l}$ which was lesser than the WHO limit. This value was lower than the value obtained by Anyanwu (2012) in Ogba River, Benin City. The mean copper concentration $(0.013 \mathrm{mg} / \mathrm{l})$ of Osse River as reported in this study was highly significant and falls within WHO limit. The concentration could be due to pollutant residual of the boating activities within the river.

Water Quality Index: The concentrations of the various considered physical and chemical parameters 
that have established regulatory values were used to determine the WQI values of the sampled stations. The Water Quality Index of all sampled stations within the study area is represented in Table 3. The excellent water quality $(8.03-9.07)$ recorded for Osse River suggests that the water is suitable for drinking and use for other domestic purposes. All four stations had excellent water quality.

Table 3: Summary of Water Quality Index (WQI) values at the

\begin{tabular}{ccc}
\multicolumn{3}{c}{ Osse River sampling stations } \\
\hline Station & WQI & Water quality \\
\hline Station 1 & 9.067605 & Excellent \\
Station 2 & 8.704997 & Excellent \\
Station 3 & 8.733481 & Excellent \\
Station 4 & 8.028244 & Excellent \\
\hline
\end{tabular}

Etim et al. (2013) reported higher WQI values (55.05 -84.94) for selected streams in the Niger Delta region, and this indicates poor water quality as a result of crude oil exploration within this region. A fairly higher WQI value (11.24 - 16.15) was recorded by Oboh and Agbala (2017) for Siluko River in Edo State, Nigeria.

Conclusion: The concentration of metals in the samples collected from Osse River indicates that the metallic ions are within background concentration level in the water body. The mean Dissolved Oxygen and Biological Oxygen Demand obtained from this study indicate the water from the study area is rated between fairly clean and clean. The Water Quality Index indicates excellent water quality. Thus, the water is presently suitable for domestic use, but increase anthropogenic activities along the river course will result in water quality deterioration in the nearest future.

Acknowledgments: This study was undertaken with the support of the Department of Animal and Environmental Biology, University of Benin and the Benin Owenna River Basin.

\section{REFERENCES}

Adebisi, AA (1981). The Physicochemical hydrology of a Tropical seasonal River Upper Ogun River. Hydrob. 79: 157-165.

Adefemi, SO; Awokunmi, EE (2010). Determination of physico-chemical parameters and heavy metals in water samples from Itaogbolu area of Ondo-State, Nigeria. Afr. J. Environ. Sci. Tech 4(3)145-148.

Admiec, E; Helios-Rybicka, E (2002). Heavy matal distribution in water of the upper and middle Odra River. Pol. J. Environ. Sci. 11(6):669-673.
Agboola, JI; Anetekhai, MA; Denloye, AA (2008). Aspects of the ecology and fishes of Badagry creek (Nigeria). J. Fish. Aquat. Sci. 3: 184-194.

Akter, T; Jhohura, F; Akter, F; Chowdhury, T; Mistry, S; Dey, D; Barua, M; Islam, M; Rahman, M (2016). Water Quality Index for measuring drinking water quality in rural Bangladesh: a cross-sectional study. J. Health Pop. Nutr. 35:4-8.

American Public Health Association (1998). Standard Methods for the Examination of Water and Wastewater. American Public Health Association. New York, USA. pp1268.

Anyanwu, ED (2012). Physicochemical and some Trace Metal Analysis of Ogba River Benin City, Nigeria. Jord. J. Bio. Sci. 5:47-54

Asaolu, S; Olaofe, O (2004). Biomagnification factors of some heavy and essential metals in sediments, fish and crayfish from Ondo State Coastal region. Bio. Sci. Res. Commu. 16: 33-39

Asaolu, S; Ipinmoroti, K; Adeyinowo, C; Olaofe, O (1997). Interrelationship of heavy metals concentration in water, sediment as fish samples from Ondo State coastal Area, Nigeria. Afr. J. Sci 1: 55-61.

Asseez, L.O. (1967). Review of the Stratigraphy sedimentation and structure of the Niger Delta. In Geology of Nigeria Ed. C.A.Kogbe. Pp259-272.

Ayas, Z; Ekmekci, G; Ozmen, M; Yerli, S (2007). Histopathological changes in the livers and kidneys of fish in Sariyar Reservoir, Turkey. Environ. Tox. Pharm. 23 (2): 242-249.

Battaglia, A; Ghidini, S; Campanini, G; Spaggiari, R (2005). Heavy metal contamination in little owl (Athene noctua)and common buzzard (Buteo buteo) from Northern Italy. Ecotox. Environ. Saf. 60:61-66.

Deekae, SN; Abowei, JF; Alfred-Ockiya, JF (2010). Seasonal Variation of Some Physical and Chemical Parameters of Luubara Creek, Ogoni Land, Niger Delta, Nigeria. Res. J. Environ. Earth Sci. 2(4): 208215.

Eddy, OA; Ukpong, EI (2002). Trace metals of upper Calabar River. Fresh Water Bio. 6:132-137.

Ekeh, IB; Sikoki, FD (2003). The status and seasonal variability in some physic-chemical parameters of the new Calabar river, Nigeria. Suppl. ad Acta Hydro. 5:45-60 
Etim, E; Odoh, R; Itodo, A; Umoh, S (2013). Water Quality Index for the assessment of water quality from different sources in the Niger Delta region of Nigeria. Front. Sci. 3:89-95.

Imoobe, TO; Adeyinka, ML (2010). Zooplankton-based assessment of the tropic state of a tropical forest river. Int J. Fish. Aqua. 2(1):64-70

Imoobe, TO; Oboh, IP (2003). Physical and Chemical Hydrology of Jamieson River, Niger Delta, Nigeria. Benin Sci. Dig. 1: 105 - 119.

Kar, D; Sur, D; Mandal, S; Saha, T; Kole, R (2008). Assessment of heavy metal pollution in surface water. Int. J. Environ. Sci. Tech. 5 (1)119-124.

Mohiuddin, K; Zakir, H; Otomo, K; Sharmin, S; Shikazono, N (2010). Geochemical distribution of trace metal pollutants in water and sediments of downstream of an Urban River. Int. J. Environ. Sci. Tech.7: 17-28.

Oboh, IP; Agbala, CS (2017). Assessment of the quality of River Siluko, Edo State, Southern Nigeria using water quality index (WQI). Afri J. Aqua. Sci. 42:279286

Odiba, J; Aremu, M; Odoh, R; Yebpella, G; Shenge, G (2014). Assessment of water quality index of borehole and well water in Wukari Town, Taraba State, Nigeria. J. Environ. Earth Sci. 4: 1 - 9.

Ogbeibu, AE (2005). Biostatistics: A Practical Approach to Research and Data Handling. Mindex Publishing Company Limited, BeninCity, Nigeria.

Ogbeibu, A; Victor, R (1995). Hydrological studies of water bodies in the okomu forest reserves (Santuary) in Southern Nigeria. Trop. Freshwater Biol. 4:83100

Ogundiran, MA; Fawole, OO; Adewoye, SO; Ayandiran, TA (2010). Toxicological impact of detergent effluent on juvenile of African catfish (Clarias gariepinus) (Buchell 1822). Agric. Biol. J. N. Am. 1: 330-342.

Olowoyo, JO; Okedeyi, OO; Mkolo, NM; Lion, GN; Mdakane, ST (2011). Uptake and translocation of heavy metals by medicinal plants around a waste dump site in Pretoria, South Africa. South Afr. J. Bot. 78:116- 121.
Omoigberale, MO; Ogbeibu, AE (2007). Assessing the Environmental Impacts of Oil Exploration and Production on the Water Quality of Osse River, Southern Nigeria. Glob. J Environ. Sci 6(1):1 - 13.

Omoigberale, MO; Ikponwosa-Eweka, O (2010). Evaluation of heavy metals of the palaemonid shrimp, Macrobrachium vollenhovenii in Ovia River, Nigeria. Biosci. Res. Commun. 22(5): 247258.

Oribhabor, BJ; Ogbeibu, AE (2009). Concentration of heavy metals in a Niger Delta mangrove creek, Nigeria. Glob. J. Environ. Sci. 8(2).

Ozturk, M; Ozozen, G; Minareci, O; Minareci, E (2009). "Determination of heavy metals in fish, water and sediments of Avsar dam Lake in Trukey”, Iran. $J$. Environ. Health Sci. Eng. 6:73-80.

Perez-Lopez, M; Cid, F; Oropesa, A; Hidalgo, L; LopezBeceiro, A; Soler, F. (2006). Heavy metal and arsenic content in seabirds affected by Prestige oil spill on the Galician coast (NW Spain). Sci. Tot. Environ. 359 : 209-220.

Rim-Rukeh, A; Ikhifa, G; Okokoyo, P (2006). Effects of agricultural activities on the water quality of Orogodo River, Agbor, Nig. J. Appl. Sci. Res. 2(5):256-259.

Tyagi, S; Sharma, B; Singh, P; Dobhal, R (2013). Water quality assessment in terms of Water Quality Index. Amer. J. Water Res. 1: $34-38$.

Umar, MA; Ebong, MC (2013). Determination of Heavy Metals in Soil, Water, Sediment, Fish and Cray fish of Jabi Lake in the Federal Capital Territory, FCT, Abuja - Nigeria. Inter. J. Res. Pure Appl. Chem. 2: 5-9.

Wayland M; Neugebauer E; Bollinger, T (1999). Concentration of lead in liver, kidney, and bone of bald and golden eagle. Arch. Environ. Contam. Toxicol. 37(2):267-272

Welcomme, RC (1979). The inland fisheries of Africa. CIFA Occassional Papers, 7: 77.

Yisa, J; Jimoh, T; Oyibo, O (2012).Underground water assessment using Water Quality Index. J. Sci. 21:33 -42 .

Yusuf, K; Osibanjo, O (2007). Nutrients in a Freshwater lagoon, Lagos, Nigeria. Pak. J. Sci. Indus. Res. 50: 232- 239. 